Journal of Universal Language 17-2

Fall 2016, 111-143

\title{
Language Preference as a Precursor to Displacement and Extinction in Nigeria: The Roles of English Language and Nigerian Pidgin
}

\author{
Joseph Babasola Osoba \& Tajudeen Afolabi Alebiosu \\ University of Lagos, Nigeria
}

\begin{abstract}
The fact that language is primarily oral makes it naturally susceptible to extinction or death. This is because there is the tendency for its speakers to abandon it as a result of their preference for a more prestigious language such as an official second language or as result of a deliberate policy of the colonial masters to discourage the development and the use of indigenous languages for their selfish reasons as well as the unwholesome adoption of the colonial master's language as official language
\end{abstract}

\footnotetext{
Joseph Babasola Osoba

Department of English, University of Lagos, Akoka, Yaba, Lagos, Nigeria

Email: jbosoba@gmail.com; josoba@unilag.edu.ng

Tajudeen Afolabi Alebiosu

Department of English, University of Lagos, Akoka, Yaba, Lagos, Nigeria

Email: jidebiosu@gmail.com
}

Received August 15, 2016; Revised September 1, 2016; Accepted September 10, 2016 
112 Language Preference as a Precursor to Displacement and Extinction in Nigeria:

after independence. Naturally, the Nigerian masses have adopted Nigerian Pidgin to cope with the multilingual nature of their metropolis. Without statistics, this sounds alarming. Because the relevant sections of the National Policy on Education has not been properly implemented, the aspect that relates to learning and using the local languages has been largely ignored by most schools in Nigeria. Using a qualitative (descriptive) and inferential approach, we attempt to examine the roles of the English language and Nigerian Pidgin viz-a-viz the gradual decline in the population of speakers and endangerment of some Nigerian languages like Efik, Ibibio, Igbo, Yoruba, and so on. A major finding is that most young Nigerians cannot speak their own mother tongues, at all or well enough, because their parents and their schools simply discourage children from speaking them at home and at school respectively where the indigenous languages are termed 'vernaculars'. Moreover, it is also discovered that most Nigerians switch between English and Pidgin depending on whether the context/nature of their communication is formal or informal. This points to the fact that our indigenous languages are being displaced, endangered, and may even be exterminated.

Keywords: language preference, indigenous languages, extinction, endangerment

\section{Introduction}

Before the amalgamation of the Northern and the Southern Protectorates of Nigeria in 1914 by Sir Fredrick Lugard, Nigerians from diverse socio-cultural, ethnic, and linguistic extractions had lived separately as different nations. But the amalgamation turned the various ethnic and linguistic nationalities into nation states under the British colonial rule with the imposition of English language as official language of administration, commerce/business and other 
official transactions. After Nigeria's independence, in 1960, the parliament had to retain the English language as Nigeria's official language because of the multi-ethnic and multilingual nature of the country and because none of the ethnic compositions was ready to forego its own language and accept another as national or official lingual franca.

Gradually, this adoption led to a situation in which the native languages have become neglected. Today, the prestige enjoyed by the English language because of its official status, functions, and roles as well as the currency and lingua franca status of Nigerian Pidgin, which has almost taken over from the native languages as the only language of Nigerian masses from diverse linguistic backgrounds, has worsened the linguistic situations. Thus this scenario has led both the English language and Nigerian Pidgin to become global languages in Nigeria. As a result, the state of our native languages has become so deplorable that prominent Nigerian linguists, such as Prof. Ayo Bamgbose and Prof. Oladele Awobuluyi, with far-reaching insights now think that they are, more or less, endangered and may eventually go into extinction. The bilingual and multilingual nature of the Nigerian nation may be considered a precipitous factor of this situation. This factor has led to language preference which can be considered a precursor to endangerment and threat of extinction of some native languages. It is therefore important to examine the linguistic situation in the present-day Nigeria.

\section{The Linguistic Situation in the Present-day Nigeria}

The linguistic situation in the present-day Nigeria appears to be precipitously complex in terms of language preference and usage. 
114 Language Preference as a Precursor to Displacement and Extinction in Nigeria:

This is because most Nigerians now tend to use non-native languages, like English and Pidgin, more often than the native counterparts in their official and unofficial capacities. Negative social attitude towards native languages and preference for prestigious non-native official and unofficial languages such as the English language and Nigerian Pidgin have been adduced as the primary cause of the gradual decline in the population of Nigerians who speak their mother tongues.

Even our traditional rulers who are regarded to be the custodians of our cultures and languages disregard them at various social occasions by speaking the English language when and where their indigenous languages would have been more appropriate. This is the case with many African countries, not just Nigeria, where many of the numerous indigenous languages are noted to be dying or going into extinction because the population of their speakers is declining and dwindling as a result of the attitude of parents who prevent their children from acquiring, learning, or speaking their mother tongues which are considered inferior, substandard, and inappropriate for social interaction in their multilingual communities (Osoba 2015; 2014a, b).

In its editorial comments of March 1, 2016, titled "Saving Our Local Languages", The Vanguard newspaper makes the following apt observations which clearly capture the linguistic scenario of local languages in Nigeria. ${ }^{13}$

a) That this year's International Mother Language Day, which fell on Sunday, February 21, 2016, served as a reminder that many Nigerian languages and dialects are among the hundreds of mother tongues on the verge of extinction.

13 http://www.vanguardngr.com/2016/03/saving-our-local-languages/ 
b) That the grave concern over the rapidly shrinking wealth of local languages and dialects in the world prompted the United Nations Educational, Scientific, and Cultural Organisation (UNESCO) to dedicate a special day for their preservation. (In fact, UNESCO has factored the use of indigenous mother languages into the 2030 Agenda for Sustainable Development. The idea is to ensure the use of local languages in the teaching of children to enable them gain a solid grounding in vernacular before embracing the orthodox languages of instruction at higher levels.)

c) That UNESCO's Director General, Irina Bukova, emphasised that mother languages "are essential components of quality education which is, itself the foundation for empowering women and men and their soceities".

d) That languages go extinct when they fall out of use and there are few people alive who can speak them. (This takes place when the act of transferring these languages from one generation to another weakens or no longer takes place because the people have turned to the use of a foreign or non-native language.)

e) That the modern phenomena of migration, urbanisation, westernization, and globalisation have wreaked great havoc on local languages, dialects, and values in Nigeria. (Few young people in urban areas, especially those of minority cultures, can speak their local languages and dialects.)

f) That even the three majority languages - Hausa, Igbo, and Yoruba - are getting endangered to varying degrees. (This is especially true for the Igbo language and dialects, maybe because of the excessive migratory patterns of Igbo speaking people.) 
116 Language Preference as a Precursor to Displacement and Extinction in Nigeria:

g) That parents are very fond of communicating with their children in English but when discussing among themselves they do so in their local dialects, thus unwittingly shutting their children away from imbibing their natural, mother tongue.

h) That we must, as a nation, wake up to the dangers of losing our local languages and dialects. (Every great nation on earth socialises the populace to communicate effectively in their local languages. They do not speak English or French in China, Russia, or any part of the Arab world. They speak their local languages. South Africa now has nine official languages, and most South Africans speak more than one of these languages. It is a product of deliberate government policy.)

i) That the Federal Government must lead in the struggle to save our languages, dialects, and values from total loss. (We should teach kindergarten and junior primary children in local languages of their choice or locality. We should encourage Nigerians to speak their languages and dialects and learn to speak other Nigerian languages. This will further our integration and strengthen our national identity.)

The scenario in Nigeria is not as a result of the lack of a language policy in Nigeria. Rather, it was precipitated or warranted by nonimplementation of the relevant sections of the nation's National Policy on Education. Today, evidence from numerous social and official interactions and occasions clearly indicate that the trend is the preference for non-native or apolitical linguistic forms such as English and NP. 


\section{Language Endangerment/Displacement}

Language displacement usually precipitates language extinction or death. When the population of the speakers of a language begins to decline rather than grow, it may lead to the extinction of that language. Language displacement which occurs in a community because of specific social environments as well as preference for a particular language or dialect in a multilingual speech community may also result in language extinction. This is perhaps why language displacement and preference usually underlie language endangerment which may later metamorphosed into language extinction.

The scenario in the Nigerian sociolinguistic milieu paints a pathetic picture of several local languages being endangered as a result of their displacement by the English language and Nigerian Pidgin (NP) in terms of their traditional roles, functions, and statuses. Blessing Eluan Douglas' (2012: 2) observation of language situation in Bayelsa State is instructive here. In the institutions of learning in this State, students seem to speak NP more than English or any of the indigenous languages because it has become the lingua franca of the people living in that part of Nigeria. The worrisome reality is that most of the local languages in the Niger-Delta region have been displaced by NP. This pathetic situation is also observable in the case of most languages, in the Middle Belt and the core north, on which the Hausa language seems to have been superimposed. Thus Hausa may be seen as a threat to the other languages of the North as they are in danger of disappearing because of the dwindling population of their speakers. A similar observation had earlier been made by Brann (1989: 230) in his suggestion that "Smaller groups can only survive ethnolinguistically if they group together with congeners and cognates ..." 


\section{Language Preference in Nigeria}

Since time immemorial, preference for one language or another has characterized the human condition in linguistically heterogeneous societies such as Nigeria, Ghana, and Tanzania. Kul (2007: 14) explains that the word Preference which comes from French préférer meaning put before, transfer, conveyance commonly refers to a choice, real or hypothetical, between alternatives. These alternatives can be rank ordered. Preference implies the existence of two opposites: preferred and dis-preferred. There can be a wide spectrum of less or more preferred between them which entails that preferences are invariably organized along a hierarchy. The concept of preferred evokes the notions of better and more frequent and, consequently, a better choice is always preferred, and, in turn, more popular in terms of distribution. In the Nigerian context, the preference for English or the local language among Educated Nigerians is susceptible to a myriad of factors such as cultural, economic, educational, and political. Language preference could therefore be viewed as a universal phenomenon which manifests itself in the way we make choices in language behavior. It is therefore imperative to examine the motivations which explain the language preference of many Nigerians.

Experiences have shown that we also indicate aspects of our social identity through the way we talk. When interlocutors engage in a discourse one can infer who they are and their speech will give a clue as to their language preference and attitudes. The social significance between the choice of words or language choice when one linguistic code is preferred to another in formal or informal domain tends to be determined by its appropriate context. For example, consider Ayomide, an undergraduate who speaks copious Nigerian Pidgin 
while in the hostel with his friends from different parts of Nigeria, who are all proficient in English, but discusses in flawless English with his professor when talking about his long essay. He, however, speaks Yoruba when he is among his friends who share his linguistic background.

Scholars are showing renewed attention by investigating the indices of these variations and why one language should take preeminence over another in social, religious, political, educational, and economic domains. The rest of the world cannot afford to wait for 'only English' usage and native-like proficiency when recent estimates of speakers of English as second, foreign or other languages out-number native speakers (Kachru 1996, Graddol 1997, Widdowson 1997, Pakir 1999, Mckay 2003, Jenkins 2006).

Language preference in Nigeria is also characterized by the sociolinguistic phenomena of code-switching and code-mixing in semi-formal contexts. Code-switching is a phenomenon of making one utterance in one language and another in a different language within the same discourse e.g., eyin akeeko o ya. Let us go 'Students, its time, let us go' (code-switching involving Yoruba and English). On the other hand, code-mixing is a phenomenon of making use of elements of two languages in the same utterance e.g., Awon footballers yen perform well 'Those footballers perform well': or $O$ sure $j u$ 'It's certain' (English code-mixed with Yoruba). Ogunnaike \& Dunhan (2010) strongly believe that the language we speak may influence not only our thoughts but also our implicit preference as well. In a study which they carried out at Harvard University it was revealed that bilingual individuals' opinions of different ethnic groups were affected by the language in which they took a test examining their biases and predilections. A question asked in one language generated a positive answer while the same question in 
another language elicited a different response: "It's like asking your friend if he likes ice-cream in English and then turning around and asking him again in French and getting a different answer." This implies that the preference for a language can elicit a positive response when the listener is favourably disposed towards such.

Many English-Yoruba bilinguals in Nigeria will prefer the use of Yoruba to English in an informal setting where the speaker puts on aso oke traditional attire). To address such a gathering using a foreign language is considered inappropriate. A personal experience I had during his National Youth Service Corps programme in Bauchi State in northern Nigeria was that a typical Hausa trader gave preferential treatment to a customer who said " $n a$ wah ni" to another who said "how much". In extreme cases, some youth corps members who cannot speak Hausa were treated with outright hostility such as "ba turenchi" or "turenchi banza" ("no English' or 'useless English', respectively). Nigerians tend to vacillate between the prestige and the local variety in their choice of either English or their native language. In the formal setting, where the use of the English language serves their utilitarian purpose, the local language tends to be less preferred but the opposite is generally the case in an informal situation because of their sentimental attachment to the local language.

Kurniasih's (2005) study on "Language Preference" among Javanese in Indonesia confirms human beings' ambivalent attitude when one language is given an enhanced status over another. Subjects in the study make comments showing that Language Preference raises the questions of identity and perception of self. "I USE Javanese because I am Javanese", "I SPEAK Indonesia because I want to get ahead as an Indonesian.” Arua's (2010) study on language preference in Botswana shows that although many of the 
children possess two or three languages, they prefer only oneSetswana, the indigenous language. However, their parents prefer them to speak English especially in school and playground. They resent the use of English at home. In the Nigerian setting too parents prefer nursery schools that adopt the 'straight for English' policy in schools where their children speak English at all times.

In revealing language loyalty leanings, preference that informs the choice of language is conditioned by sociolinguistic variables such as the interlocutor, the subject of discourse, the purpose of discourse as well as the occasion. For example, an educated Nigerian may use English among some friends who do not speak his own first language even when his attitude to the language is ambivalent. In other words, the choice of language is dictated primarily by the milieu in which the speaker finds himself. Therefore, educated Nigerians may hate what the English language is doing to their mother tongues but they love its effectiveness in getting along when they consider its economic, social, political, and educational importance. A mini language survey we carried out to investigate the language preference of some Nigerians to an indigenous language (Yoruba) and English in formal domains reveals interesting results enough to provoke fresh insight about new inroads the English language has made in Nigeria's sociolinguistic landscape.

Subjects consist of 800 respondents who were asked to tick a corresponding box to their preferred options which include: Strongly Agree (SA), Agree (A), Disagree (D), and Strongly Disagree (SD). They were drawn from across the South-West and North-Central geo-political zones of the country where Yoruba language is spoken. The selection was done through a stratified sampling technique and respondents were drawn from the South-West zone comprising the following states: Lagos, Ogun, Osun, Ondo, Oyo, and Ekiti, 
122 Language Preference as a Precursor to Displacement and Extinction in Nigeria:

(LOOOOE) States; and the North Central zone comprising Kwara and Kogi (KK) States on the basis of 100 participants per state. Nwana (1981: 70) argues that "there is no fixed and inviolate rule regarding the size of the sample". Subjects for the study were in two categories. The first, numbering 400 were those who have had secondary school education. The second category was also 400 comprising those who have had some form of higher education like University, Polytechnic, College of Education or equivalent.

Table 1. Yoruba-English Bilinguals' Preference for Use of English in Formal Domain

\begin{tabular}{|c|c|c|c|c|c|c|}
\hline $\mathrm{S} / \mathrm{N}$ & ITEM & SA & $\overline{\mathbf{A}}$ & SD & D & TOTAL \\
\hline $\begin{array}{c}1 \\
(\mathrm{SE})\end{array}$ & $\begin{array}{l}\text { I prefer } \\
\text { speaking } \\
\text { English } \\
\text { most often }\end{array}$ & $\begin{array}{r}250 \\
31.25 \%\end{array}$ & $\begin{array}{r}350 \\
43.75 \%\end{array}$ & $\begin{array}{r}95 \\
11.875 \%\end{array}$ & $\begin{array}{r}105 \\
13.125 \%\end{array}$ & $\begin{array}{r}800 \\
100 \%\end{array}$ \\
\hline $\begin{array}{c}2 \\
(\mathrm{RE})\end{array}$ & $\begin{array}{l}\text { I read better } \\
\text { in English }\end{array}$ & $\begin{array}{r}235 \\
29.375 \% \\
\end{array}$ & $\begin{array}{r}360 \\
45 \% \\
\end{array}$ & $\begin{array}{r}95 \\
11.875 \% \\
\end{array}$ & $\begin{array}{r}110 \\
13.75 \% \\
\end{array}$ & $\begin{array}{r}800 \\
100 \% \\
\end{array}$ \\
\hline $\begin{array}{c}3 \\
(\mathrm{WE})\end{array}$ & $\begin{array}{l}\text { I write more } \\
\text { letters in } \\
\text { English }\end{array}$ & $\begin{array}{r}252 \\
31.5 \%\end{array}$ & $\begin{array}{r}365 \\
45.625 \%\end{array}$ & $\begin{array}{r}95 \\
11.875 \%\end{array}$ & $\begin{array}{r}88 \\
11 \%\end{array}$ & $\begin{array}{r}800 \\
100 \%\end{array}$ \\
\hline $\begin{array}{c}4 \\
(\mathrm{PE})\end{array}$ & $\begin{array}{l}\text { I Prefer } \\
\text { English to } \\
\text { Yoruba as } \\
\text { official } \\
\text { language }\end{array}$ & $\begin{array}{r}160 \\
20 \%\end{array}$ & $\begin{array}{r}280 \\
35 \%\end{array}$ & $\begin{array}{r}140 \\
17.5 \%\end{array}$ & $\begin{array}{r}220 \\
27.5 \%\end{array}$ & $\begin{array}{r}800 \\
100 \%\end{array}$ \\
\hline
\end{tabular}


Figure 1. Yoruba-English Bilinguals' Preference for Use of English in Formal Domain

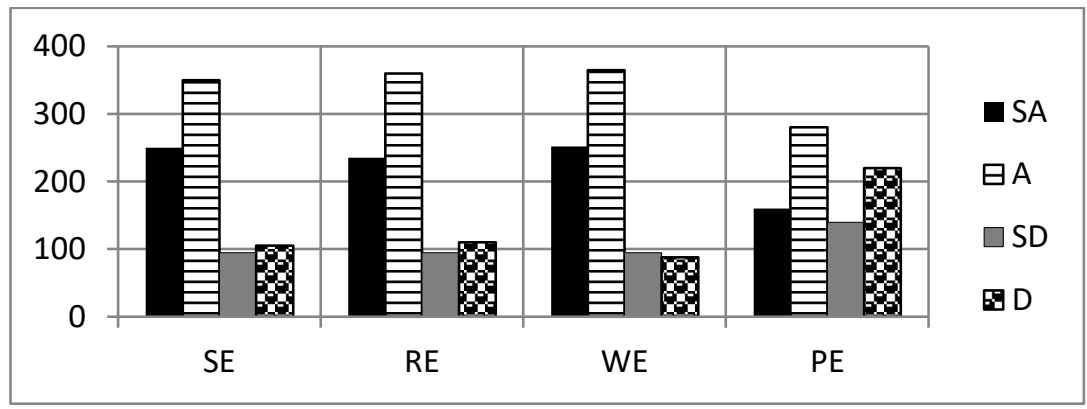

* $\mathrm{SE}=$ Speak English Most Often, RE $=$ Read Better in English, WE = Write More in English, PE = Prefers English.

The preference for the preponderance use of English in the formal domain validates the role English plays in the day to day lives of the respondents being a second language in Nigeria.

\section{Language Death/Extinction}

The idea of language death presupposes its opposite, language birth. Where one superordinate language is imposed on others in a survival of the fittest struggle, the dominant language may swallow the 'inferior' ones leading to language endangerment and subsequently extinction and death. However, depending on the linguistic geography and sociopolitical structure of the society new languages may evolve as in Pidginisation and Creolization as observable in many parts of the world. Crystal (2000) affirms that "a language dies when nobody speaks it anymore". A language thrives and survives as long as someone speaks it and has someone to speak 
124 Language Preference as a Precursor to Displacement and Extinction in Nigeria:

it to. United Kingdom Foundation for Endangered Languages (FEL) reported the Mambilla case in Adamawa province where Kasabe language died when Boyon the last speaker died just before the researcher could complete an attempt to rescue the language from going into extinction. A situation where a language existed on 4th November, 1995 but ceased to exist the next day paints a grim picture of the challenges sociolinguists face on the reality of Language endangerment and death.

Brezinger (1998) argues that language death has always been taking place in Middle Belt Nigeria. He gave an example of the sociolinguistic situation regarding major expansions of languages that led to turmoil in the area because many languages have disappeared due to language displacement and assimilation. Hausa, Kanuri, and Tiv enjoy a lot of patronage but often Hausa is always overriding other languages. The Basawa people who once had Bassa as their major language now speak only Hausa.

The Nigerian situation has witnessed some of these recognizable factors responsible for language death. According to Brezinger (1998) a language moves from endangerment to death when:

1) It is assimilated to larger, more powerful groups nearby.

2) It is assimilated to smaller but culturally dominant groups.

3) It is assimilated to English as an official language.

4) It is assimilated to demographic crises caused by labour migration and urbanization.

In South-west Nigeria, Yoruba as the lingua franca has dominated other variants of its type. For example, Ijebu, Ilaje, Ikale, Ondo, Igbomina, Egun, Egba are all subsumed under Oyo Yoruba which is regarded as Standard Yoruba due to its sociopolitical importance. 
However, Crystal (2000) strongly believes that Yoruba has been called 'deprived' because of the way it has come to be dominated by English as the language of higher education in Nigeria.

Language death of some Nigerian languages in the north was reported by Ujorha (2013) where he talks of the 'The Dying Languages of Illo' in Kebbi state. The study shows that many of the languages spoken in Ilo are dying. The older generations speak the languages, but the younger generation can hardly utter their mother tongues. However, they speak a lot of Hausa, and their fluency in the tongue improves with every passing day. Today, they are already rivalling native speakers of Hausa. Languages such as Zabarmanci, Dandanci, and Busanci are declining rapidly. The district head of the area Mallam Tudun Giri lamented that:

Hardly would you find people who can speak these languages fluently today, without putting in some words of Hausa. Hausa had significantly influenced these languages, and it has come to dominate the other languages. When you go to the large Lolo market, you will find people speaking these languages, but you will see that generally they are now Hausa speaking population. The younger generations are not being taught the language.

Professor Gbenga Ibileye of the Department of English, Ahmadu Bello University, Zaria, who sees this development as a looming extinction sheds light on the factors which endanger a language. He explains that:

A major indicator of an endangered language is when the younger people of the community no longer speak the 
language. If you make a cursory assessment of these languages, you find that children no longer speak these languages, rather they speak English. When the present generation of older people go, we will be left with children who cannot speak their indigenous languages, including the so-called major Nigerian languages.

Mallam Mamman's article of March 3, 1985 in Sunday New Nigerian gives a strident dimension towards a decolonization of our languages. He argued that for the survival of their languages, Nigerians should forget their differences and unite for a common goal, a goal of waging war against the English language, a war of decolonizing our languages before our next generation will one day wake up to find themselves speaking English as their only language. He warned that it would be unfortunate and shameful for them to come and discover that they will have no cultural heritage (linguistically) to hand over to their own children except the foreign one.

\section{The Role of English in Nigeria's Socio-Cultural Milieu}

The Nigerian society remains one of the most complex speech communities in the world (Bamgbose 1991, Banjo 1995). Since language use or usage is determined by sociolinguistic factors such as age, status, education, location, gender, and so on, the linguistic scenario in most of 36 States of the Federation and the Federal capital territory has remained diverse and complex with English language as a major interactional language among the vast populace 
in many cities. The exchange below exemplifies the great divide between many Nigerians on the role of the English language in Nigeria's socio-cultural milieu.

Citizen A: We must use it. It is the language of national unity. It fosters interethnic communication. It is a global language.

Without it, Nigeria is doomed.

Citizen B: Don't use it. It is a foreign language.

It destroys our culture.

It is a killer language swallowing other

languages on its path.

We need our own national language.

'Tiwa ntiwa'. Ours is ours.

Despite the ambivalence exhibited by these two citizens, it is indisputable that English has come to play a central role in the national, political, and socio-cultural lives of Nigerians. The multilingual needs of the modern day world citizen require him to reckon with the all-purpose utilitarian functions of the English language. Due to globalization and eco-tourism the world has shrunk to fit the palm.

The following is an overview of the role of English in Nigeria's socio-cultural landscape:

\section{1) As a Lingua Franca:}

Nigeria's multilingual nature has propelled English to enjoy unrivalled dominance as a neutral language or no man's language. Major ethnic groups competing for national identity and survival feel at home in a common 
tongue that belongs to none. Not surprisingly, Bamgbose (1991) submits that of all the heritage left behind in Nigeria by the British ... none is more important than the English language. English is the only effective medium of communication between Nigerians from different linguistic backgrounds. When parties and social gatherings like house warming, naming ceremonies and church programs are organized English is invariably the medium of communication because of the diverse nature of the audience. The English language is therefore regarded as the language of national unity.

\section{2) Official language:}

All government affairs in Nigeria are conducted in English. These are official memos, gazettes, edicts, law reports, and Hansards. The national anthem and the pledge are worded in English. English is the language of presidential address and transactions. The constitution of Nigeria is fashioned in English and only feeble attempts are made to translate it into indigenous languages. The coat of arms, the national flag, motions for bills in state houses of assembly, and the national assembly are couched in English.

\section{3) Language of the Mass media:}

Almost all the media use English to transmit information to the masses. All the national newspapers like The Guardian press, The punch, The Tribune are all published in English. Radio and television programmes are broadcast in English. News reports and analyses are conducted in English. Magazines, sports, tabloid, and gossip periodicals are all written in the English language. 


\section{4) Language of Education:}

The National Policy on Education (NPE) bestows unqualified dominance of the English language right from the early life of the Nigerian child. Section 3 paragraph 15(4) of the National Policy on Education (NPE 2005) revised, stipulates that English should be used at the later stage of primary education. This implies that at basic 4 primary educations, the Nigeria child's exposure to English has started in earnest. Even where the community is linguistically heterogeneous like Lagos and Jos, a straight for English or early English medium policy is adopted right from the first day in school. Some school even label their classes Do not speak vernacular with the implication that English enjoys more prominence over the local languages. Wole Soyinka's plays, Chinua Achebe novels, Encyclopedias, Dictionaries, and reference sources in the library are accessed in English. All courses in our higher institutions including law, medicine, engineering, etc. have their curriculum content fashioned in English. Admission to higher institutions depends on a credit level pass in English. Proficiency courses in English like TOEFL, TESL, and SAT are run to enable Nigerians get overseas education. This is to prepare them for educational advancement and prestigious employment.

\section{5) Language of Business and Commerce:}

English is used for trading transactions among the various ethnic groups in the country. Industrial advertisements like Life is Good for L.G. products, Rule your world by GLO, Happy customer, happy banking by some commercial banks are common in the business world. 
130 Language Preference as a Precursor to Displacement and Extinction in Nigeria:

Cheques, tellers, invoices, and proposals are prepared in English. Business records and contracts are similarly drawn in the English language.

6) Language of External Affairs:

The international status of English requires Nigeria to adopt it for external affairs. Organs like United Nations (UNO), African Union (AU), World Health Organization (WHO), Economic Community for West African States (ECOWAS) are a comity of nations which uses English as a global language.

7) Language of Information and Communication Technology (ICT):

With the coming of the internet, English has been given higher responsibilities. Known as the information super highway, web surfing, cyber spacing, chartroom, face booking, e-mailing, and text messaging have rubbed off on Nigeria as a result of globalization. Computer experts have argued that the computer speaks English. If any global citizen wishes to engage in a digital discourse, the common currency required is the use of English through the internet. Some $80 \%$ of the on-line contents are in English. Many Nigerians are now getting internet compliant as upward mobility and international exposure are now becoming increasingly digitalized. Our professors hitherto known as eggheads are now referred to as net-heads.

It is however interesting to remark that English has started to make inroads into some areas formerly regarded as sacrosanct and which are the preserve of Nigeria's culture and tradition. Our royal 
institutions now engage in discourse using the English language as more roles are now assigned to it even in informal setting in Nigeria. Adegbite \& Babalola (2008) illustrates that the Olubadan of Ibadanland, a renowned royal father in South-west Nigeria attunes his choice of language to the prevailing situation. He addresses (i) representatives of traders' associations in Yoruba, (ii) a group of visiting academics of Ibadan origin in both Yoruba and English, (iii) a group of journalists in English, and (iv) a group of mixed (i.e., Yoruba and non-Yoruba) visitors in English. Similarly, when a fund raising activity was organized in a communal setting a distinguished professor of Yoruba was requested to present the guest lecture in English in order for the address to get to a wider audience. Of course, the professor had to oblige, in his own words, against his personal wish and desire. While nothing may be inherently wrong with the organizers' goal of reaching a wider audience, one may ask if the preference should not be for the immediate audience who are mainly Yoruba.

However, a breath of fresh air came with some institutional efforts like those of Adekunle Ajasin University, Akungba in Ondo State which delivered its 2013 convocation address in Yoruba language. Titled: 'Kini A Fe Fi Ede Yoruba Se?' ('What do we do with Yoruba language?'), the lecture was given by the renowned literary and academic author, Professor Akinwunmi Ishola. This is a watershed among the academia in the efforts towards the revalorization of our indigenous languages. Concerted efforts are therefore required to further sanitize our cultural sense of belonging as the indigenous languages now being given a new breath of life and safety net from the brink of extinction. 


\section{The Role of Nigerian Pidgin in Nigeria's Socio-Cultural Milieu}

The role of Nigerian Pidgin in Nigeria's socio-cultural milieu has been well-explicated by Osoba (2014a) where it is noted that the growing popularity of Nigerian Pidgin (NP) is not restricted to only social interaction, but dating back to the early 60's, its adoption by the late foremost Nigerian jazz and popular music icon, Fela Anikulapo Kuti, apart from Yoruba, his mother tongue, as the language of his music. Thus from the 1960's until his death in 1997, much of his music was in Nigerian Pidgin. This well-documented fact by Carlos Moore (2010: 1) affirms that much (about 90\%) of his works from the 1970s until his death in 1997 was in Pidgin. Moreover, in a Special Lecture at the Faculty of Arts, University of Lagos, on October 13, 2010, Carlos Moore strongly advocated the use of Nigerian Pidgin as a national lingua franca as Agheyisi (1984), Elugbe \& Omamor (1991), Osoba (2000), and others had earlier suggested.

Not surprisingly, NP has had a phenomenal growth as a common language in Nigeria today. Realistically, empirical evidence now suggests it has the widest currency among Nigerians from diverse ethnic and linguistic backgrounds. Curiously, this currency tends to be a reflection of language choice or preference of Nigerians from all walks of life in music, social interaction, religious activities/events, mass media broadcasting, and literary works even at the primary level of education in places like Asaba Warri, Sapele, and PortHarcourt. More so, its profile in Ajegunle Town, advertises it as adorable lingua franca for residents from diverse ethnic and linguistic backgrounds. In terms of function, form, structure, and status, it is a prestigious creole for the vast majority of those who 
now speak it as a primary or first language. The precipitation of this unusual development of the NP, noted by Donwa-Ifode (1984), in the use of Nigerian Pidgin (NP) in Port-Harcourt has graciously led to its unofficial adoption as lingua franca of the Nigerian masses.

As already noted many published and unpublished literary works either fully or partly written in Nigerian Pidgin such as Major General Mamman Vatsa's poem, 'Tori for Get Bow Leg'; Ken Saro Wiwa's 'Soza Boy'; Aig Imoukhuede's 'My Pidgin Stew and Sufferhead'; Fadaka's Pidgin Translation of the Universal Human Rights can be found in their hard copies or electronic version on the internet. In the works of prominent Nigerian literary icons such as Wole Soyinka, Chinua Achebe, Festus Iyayi, Gabriel Okara, and Niyi Osundare, Nigerian Pidgin (NP) can be clearly seen as prominent.

Moreover, the elite covertly appear to enjoy the flavor and air of fun and cordiality that Nigerian Pidgin profusely and naturally exudes, especially in informal situations. Thus this trend, in its currency, is most visible in the mass media (television, radio, magazines, and newspapers), hospitals, police stations, schools, higher institutions of learning, government offices, etc. In Nigeria's democratic dispensation, NP has become embraced as the language of political jingles and campaigns by politicians and political jobbers to woo the masses and win their votes in the electronic and print media. This strategy was adopted by the late Chief MKO Abiola (1993 Presidential Elections), ex-President Goodluck Jonathan (2011 Presidential Elections), and President Mohammed Buhari (2015 Presidential Elections) to win their various elections (Osoba 2014a: 26-27).

Blessing Douglas' (2012), in an unpublished Master of Arts' dissertation entitled "The Status of Nigerian Pidgin and Other 
134 Language Preference as a Precursor to Displacement and Extinction in Nigeria:

Indigenous Languages in Bayelsa State Tertiary Institutions", provides a succinct picture and analytical details of the worrisome linguistic milieu in most of the tertiary institutions in that particular State. While focusing on the comparative status of Nigerian Pidgin among local indigenous languages in regions where it is in common use, she identifies the preference of NP in place of mother tongues and English (except in situations requiring strictly only English) by majority of her subjects who were tertiary institution students. With that trend, her conclusion is the inevitability of NP completely displacing the ethnic languages in the parts of the State which constituted her sample population. Sadly, one of her observations is that, as a result of the preference for NP, many of the students in the tertiary institutions in the State could not improve their performance and competence in English and their mother tongues (Douglas 2012: 87). Some of her findings are encapsulated in the following tables (ibid: 60):

Table 2. Percentage Distribution of the Respondents by Frequency in the Usage of Nigerian Pidgin

\begin{tabular}{|c|c|c|}
\hline $\begin{array}{l}\text { How often do you use Pidgin } \\
\text { English in your day-to-day } \\
\text { interaction with fellow students }\end{array}$ & Frequency & Percentage \\
\hline Often & 77 & 38.9 \\
\hline Very often & 69 & 34.84 \\
\hline Seldom & 32 & 16.16 \\
\hline Not at all & 20 & 10.10 \\
\hline Total & 198 & 100 \\
\hline
\end{tabular}


Figure 2. Percentage Distribution of the Respondents by Frequency in the Usage of Nigerian Pidgin

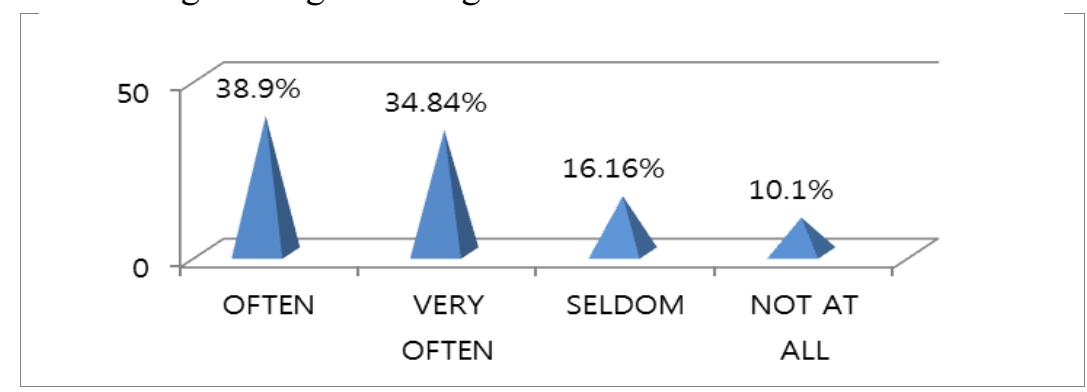

The frequency table analysis showed that $38.88 \%$ often use Nigerian Pidgin in their day-to-day interaction with fellow students, followed by $34.34 \%$ that spoke it very often. On the other hand, $16.16 \%$ seldom spoke it while $10.10 \%$ of the entire group did not speak Pidgin at all.

\section{The Effects of the Roles of English and Nigerian Pidgin as Global Languages}

The roles and status of English and Nigerian Pidgin as global languages have effects which can be linked to the precarious state in which our native languages have found themselves in Nigeria today. As espoused by Osoba (2014c: 71-74), this deplorable scenario was precipitated by both external influences and lack of interest in their use and development by the natives as a result of their preference for global languages. This point was illustrated with a warning lamentation by Professor Wande Abimbola, a former ViceChancellor of the Obafemi Awolowo University, Ile-Ife, at the 3rd Oodu'a Distinguised Lecture, in November 2010 that: 
the language of Yoruba and all enviable Yoruba cultural endowments could go into extinction ... In most homes, some educated people now find it difficult to communicate with their children in their mother tongue.

From his observations, it appears that the Yoruba indigenes may have lost or are losing much of their cultural endowment like drumming, songs, folktales, and dressing because of their recognition of the English language at the expense of their mother tongue. The reason for this is not far-fetched.

The attitude of Nigerians to their indigenous languages tends to be negative in both formal and informal situations. Most parents tend to discourage their children or wards from using their mother tongues especially at school and among extended family members and friends while encouraging them to speak favoured English. This negative attitude can also be noted when family members exchange greetings or pleasantries in English rather in their mother tongues.

This phenomenon has been observed not to be peculiar to Nigeria but rather global since it is found in most countries where English is used as a second language. In a paper by Charity Turano \& Mary Malimas (2013: 61-83), it is clear, from their findings, that Filipino children prefer to use English both at home and at school as a result of their parents' and teachers' positive disposition to English.

Buttressing this point, an apt reference is made to the fear expressed by the Chairman, Governing Board, that "some Nigerian languages may suffer total extinction in a few years due to neglect National Institute for Cultural Orientation, Ambassador Abubakar Ibrahim Ganyama, in August 2010 by organisations and other bodies responsible for language and cultural preservation in Nigeria."

However, a graphic picture painted in the Vanguard of September 
23, 2011 in an opinion column entitled "Nigeria: Saving Igbo Language from Extinction" is said to make the situation desperately pathetic. The extract below is shown as an index and portrayal of the situation of most indigenous languages in Nigeria:

1) ... some decades ago, stories were told about school children being slammed with all manners of punishment for speaking Igbo in the classroom!

2) ... any student that offered Igbo language in school certificate examination was laughed to scorn.

3) ... Back in individual Igbo homes, parents no longer told scintillating, entertaining, and educative folktales to their children. Several families no longer find it fashionable to talk to their children in Igbo language or teach them Igbo idioms and proverbs.

4) Everyman, irrespective of his relationship to an Igbo child of this day and age, has since transformed into an "uncle". For the women, they turned "aunties".

The question then is, if the above points are true of Igbo, one of the three major Nigerian languages, they must be true of all or most of our indigenous languages today.

\section{Panacea for Revalorization/Revival of Interest in Indigenous Languages}

Having highlighted the sorry state of our indigenous languages, we now provide panacea for their revalorization/revival of interest. It is our candid belief that the situation can be addressed by language 
138 Language Preference as a Precursor to Displacement and Extinction in Nigeria:

empowerment and cultural awareness. International organisations like Centre for Blacks and African Arts and Civilization (CBAAC) should be encouraged to continue to give impetus for the promotion of African languages as tools for sustainable growth and development.

The mass media should also be encouraged to propagate and consolidate the enhancement of our indigenous languages. Broadcast, debates, and dramas should be carried out in these languages so that we can further preserve our identity. It is disheartening to note that $70 \%$ of the programmes aired on our radios and televisions are laden with English. Despite the National Broadcasting Corporation guidelines stipulating high percentage local content, many media outfits find it convenience to flout such directives. With the deregulation of the broadcasting industry, many private owners prefer most of their programmes aired in English. This must change if we want our indigenous languages to develop beyond the present state.

Private contributions like those of Yeye Olade of African Heritage Research library, Ibadan will boost the status of the local languages if nurtured to fruition. As a black American, who returned to Nigeria for language and cultural rejuvenation, she pioneered a sociolinguistic experiment which recognizes pure Yoruba as the correct form of communication. In an article in The Guardian of August 3, 2005, she describes expressions like 'Kilo happen', 'kosi problem', 'Keni nice day', etc. as:

an attempt to give prominence to English which is a readymade weapon of British-American cultural imperialism that tends to destroy not only African languages but also attacking other languages worldwide (ibid: 65). 
Her stern recommendation is the French government measures, which threaten to sack French broadcasters who pollute French with English in general French conversation. She strongly advocates the principle of 'War Against English Words Entering Yoruba' and enjoins clubs and organizations to float 'Best Yoruba Speaker Award' which must be sponsored at local and national levels. In her view, that notable writers like Nobel Laureate Wole Soyinka should have bilingual publications of their works. While some scholars may see Yeye Olade's position as avant-garde or xenophobic, it is possible that a moderate adaptation of her recommendations will go a long way in giving an impetus to the enhancement of our indigenous languages.

The Federal and State Governments should revive the moribund language centres and encourage language development activities. There should be some enforcement of the language policy that each State Assembly should conduct debates and deliberations in the constitutionally recognized national languages apart from English as done in Lagos State.

Orthographies of the local languages should be developed and more terminologies evolved to reflect modern experience. With the advent of information technology, the indigenous languages should be given their right of place.

Apart from the fact that Google has listed Yoruba in its search machine, a pioneering initiative known as the Kamusi project has been launched by Yale University in America aimed at translating African languages and learning/teaching Kiswahili on the Internet. Websites on local language centres and relevant information are now accessible in the interest making the web a new space for African languages. Other languages listed to benefit from the Yale Experiment are Nigeria's Hausa, Uganda's Luganda, Kenya's 
Kikuyu, Burundi's Kirundi, and Somalia's Somali. It is a welcome development that the Internet now serves as a platform for Africans to communicate with friends and relatives in their indigenous languages now being given a new breath of life and safety net from the brink of extinction. Similar efforts should be replicated at home.

\section{Conclusions}

Having explicated the precarious state of our indigenous languages in Nigeria, we propose that some if not all of the measures adduced in Section 9 be taken in other to stem the worsening trend and avert a catastrophic situation resulting in the extinction or death of our beloved cultures, ethnicities, and languages. Our study reveals that there is now a general trend of preference for the choice of English for interaction in formal and informal contexts. Some Nigerians are also beginning to use English and Pidgin more than local languages. The dominance and over-utilization of English to the detriment of other indigenous languages cannot but have some negative effects on our national aspirations. The paper affirms that if Nigeria is to make a distinctive contribution to global progress, there has to be synergy between English and the indigenous languages by harnessing linguistic resources without foreclosing the contributions that any of these languages can make. We also suggest possible ways of assigning more roles to the indigenous languages in several domains to prevent a situation where the English language will obfuscate not only the Nigerian cultural values but its linguistic independence. The onus is on the government and the entire citizenry to demonstrate more commitment towards the empowerment of the indigenous languages. Our traditional rulers, language scholars, the mass media, 
novelists and concerned patriots must put all hands on deck to resuscitate some of Nigerian languages on the brink of extinction.

\section{References}

Adegbite, W. \& E. Babalola. 2008. Sociological Dimensions of Bilingual Communication in Yoruba and English in a Cosmopolitan City: A Case Study of Ibadanland. Available at $<$ www.researchgate.net $>$, Assessed on August 1, 2016.

Agheyisi, N. 1984. Linguistic Implications of the Changing Role of Nigerian Pidgin English. English World-Wide 5.2, 211-233.

Arua, E. 2010. Patterns of Language Use and Language Preference of Some Children and Their Parents in Botswana. Botswana: University of Botswana.

Bamgbose, A. 1991. Language and the Nation: The Language Question in Sub-Saharan Africa. Edinburgh: Edinburgh University Press.

Bamgbose, A., A. Banjo \& A. Thomas. 1995. New Englishes: A West African Perspective. Ibadan: Mosuro.

Banjo, A. 1995. On Language Use and Modernity in Nigeria. Ibadan: Group Publishers.

Brann, C. 1989. A Sociolinguistic Profile of Nigeria's Northern and Eastern Borders. In A. Asiwaju \& P. Adeniyi (eds.), Borderlines in Africa 213-245. Lagos: University of Lagos Press.

Brenzinger, M. (ed.) 1998. Endangered Languages in Africa. Cologne: Koppe.

Crystal, D. 2000. Language Death. London: CUP.

Donwa-Ifode, S. 1984. Is Nigerian Pidgin English Creolising? Journal of the Linguistic Society of Nigeria 2, 99-203. 
142 Language Preference as a Precursor to Displacement and Extinction in Nigeria:

Douglas, B. 2012. The Status of Nigerian Pidgin and Other Indigenous Languages in Bayelsa State Tertiary Institutions. Unpublished M.A. Thesis, Obafemi Awolowo University. Elugbe, B. \& A. Omamor. 1991. Nigerian Pidgin: Problems and Prospects. Ibadan: Heinemann Educational Books Nigeria Plc. Graddol, D. 1997. The Future of English? [Electronic version]. London: The British Council. Retrieved April 6, 2007, from $<$ http://www.britishcouncil.org/>.

Jenkins, J. 2006. Current Perspectives on Teaching World Englishes and English as a Lingua Franca. TESOL Quarterly 40.1, 157181.

Kachru, B. 1996. World Englishes: Agony and Ecstasy [Electronic version]. Journal of Aesthetic Education 30.2, 135-155.

Kul, M. 2007. The Principle of Least Effort within the Hierarchy of Linguistic Preferences: External Evidence from English. Ph.D. Dissertation, School of English, Adam Mickiewicz University.

Kurniasih, Y. 2005. Gender, Class, and Language Preference: A Case Study in Yogyakarta. Paper presented at the ALS conference. Melbourne: Monach University.

McKay, S. 2003. Toward an Appropriate EIL Pedagogy: Reexamining Common ELT Assumptions. International Journal of Applied Linguistics 13.1, 1-22.

Moore, C. 2010. Fela: This Life of a Bitch. Abuja: Cassava Republic Press.

Nwana, O. 1981. Introduction to Educational Research. Ibadan: Heinemann.

Ogunnaike, O. \& Y. Dunham. 2010. The Language of Implicit Preferences. Journal of Experimental Social Psychology 46.6, 999-1003.

Osoba, J. 2000. Tense and Aspect in Nigerian Pidgin. Ph.D. Dissertation, University of Lagos. 
. 2014a. The Use of Nigerian Pidgin in Media Adverts. International Journal of English Linguistics 4.2, 26-37. . 2014b. The Use of Nigerian Pidgin in Nigerian Political Jingles. Journal of Universal Language 15.1, 105-127. . 2014c. Language, Education, and Manpower Development in the Present-Day Nigeria. Cuttington University Journal of Liberal Arts \& Social Sciences 1.1, 71-89. 2015. Analysis of Discourse in Nigerian Pidgin. Journal of Universal Language 16.1, 1-29.

Pakir, A. 1999. Connecting English in the Context of Internationalization. [Electronic version]. TESOL Quarterly 33.1, 103-114.

Turano, C. \& M. Malimas. 2013. Medium of Instruction for K1Grade 3 in the Private Schools in Cebu City: Revelations of Language Preference, Usage, Exposure, and Views of Students. Philippine Journal of Linguistics 44.2, 61-82.

Ujorha, T. 2013. Saving Our Local Languages. In Daily Trust Nigeria Vanguard. Available at <http://www.vanguardngr.com/ 2016/03/saving-our-local-languages/>.

Widdowson, H. 1997. The Forum: EIL, ESL, EFL: Global Issues and Local Interests. [Electronic version]. World Englishes 16.1, 135146.

Daily Trust Nigeria, November 16, 2013.

Sunday New Nigerian, March 3, 1985.

Vanguard, September 23, 2011. 